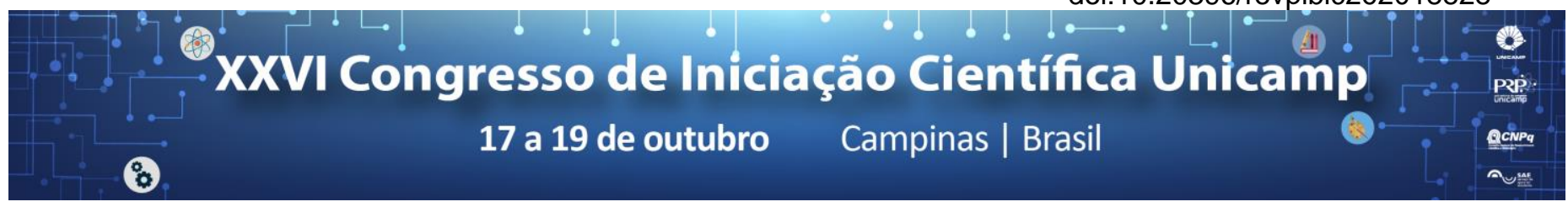

\title{
Processo de Internacionalização dos Grandes Bancos Chineses
}

\section{Leonardo Santana Rocha dos Santos, Ana Rosa Ribeiro de M. Sarti}

\section{Resumo}

O projeto em questão tem como objetivo analisar o processo de internacionalização do sistema financeiro chinês em suas especificidades, como a estruturação diante o cenário externo no começo dos anos 2000 até a atualidade e os mecanismos adotados pelo governo chinês, altamente participativo nesse procedimento, que o tornam singular diante outros processos de abertura do sistema financeiro.

Ainda, serão colocadas em comparação dados coletados por veículos de informação especializados referente ao Market share que bancos estrangeiros partilham com bancos estatais nacionais, capital acumulado em reserva, linhas que esses bancos procuram atender e quais são as peculiaridades desse arcabouço.

\section{Palavras-chave:}

Bancos chineses, Sistema financeiro chinês, Internacionalização.

\section{Introdução}

O acentuado crescimento da economia chinesa verificado nas últimas décadas encontra-se diretamente relacionado aos rumos tomados por seu sistema financeiro a partir de 1980. Desde então, uma série reformas modernizadoras, adequadas a um contexto de intensificação do processo de abertura econômica do país, foi colocada em prática sob a tutela de Deng Xiaoping.

bancária, ao contrário do que inicialmente poderia se imaginar, acentuou a força de tais instituições dentro dos cenários nacional e mundial. (GIRARDIN, 1997).

Assim, o objetivo principal deste trabalho é realizar uma detalhada caracterização da internacionalização do sistema financeiro chinês, assim como uma análise pormenorizada de suas principais diferenças no processo de internacionalização.

Ademais, será tratada tão igualmente os impactos dessa internacionalização em um cenário mundial e quais foram as possibilidades de expansão chinesa, dada as especificidades de seu processo de internacionalização e como este se comportou diante outros nexos financeiros.

\section{Resultados e Discussão}

O fenômeno da globalização financeira intensificado nas últimas décadas do século $X X$, se disseminou por todas as regiões do mundo. Até mesmo a China, país marcado por seu isolacionismo econômico até o final da década de 1970 e por seus aspectos políticos restritivos, apresenta-se atualmente ativa nos processos de financeirização e inserção comercial.

Suas instituições bancárias, outrora completamente administradas pelo Estado, abriram-se ao capital (embora que de maneira extremamente controlada) estrangeiro e procuram incessantemente oportunidades de atuação no exterior. Os denominados "Big Five", apesar de ainda contarem com forte suporte governamental, passam a depender cada vez menos dos rigorosos mecanismos de supervisão e controle estatais.

A discussão nos leva até mesmo a pensar no possível papel do iuane como moeda internacional de reserva. Apesar de ainda haver uma série de restrições por parte das principais potencias econômicas a respeito da credibilidade da moeda chinesa, o iuane passa a figurar de forma cada vez mais intensa na economia mundial. .

\section{Conclusões}

Adotando uma estratégia ousada de condução econômica, pautada em estímulos maciços aos investimentos (principalmente em infraestrutura - foco nos setores de transporte e energia), o governo chinês estabeleceu os alicerces necessários para a criação de uma trajetória de crescimento quase ininterrupta da economia nacional. A intensificação dos movimentos de liberalização e internacionalização constituiu-se apenas em mais um pilar da estratégia articulada, de forma que o capital estrangeiro passou a ocupar posição de destaque no cenário econômico chinês, porém sem colocar de fato em risco a soberania nacional.

Assim, a análise dos recentes movimentos de internacionalização do capital bancário chinês deve estar atrelada a esse cenário de mudanças que permeia o ambiente socioeconômico do país. O incentivo a práticas isolacionistas por parte do governo cede espaço para a adoção de parcimoniosas estratégias de inserção financeira em outros mercados, com ampliação de rede de negócios e expansão de parcerias comerciais.

\section{Agradecimentos}

Aos meus pais, David Raimundo dos Santos e Luciana Ap. de Santana R. dos Santos, pelo consolo, durante momentos de decepção, e pelas congratulações, no saboreio das conquistas. Afeição e apoio incondicionais em ambos os casos.

Á Professora Ana Rosa, pela disponibilidade e atenção durante o desenvolvimento desse projeto. Por entender minhas dificuldades e angústias, se fazendo presente como profissional de exímio conhecimento e humanidade. Espero que essas inúmeras qualidades reflitam numa mudança para melhor escolha de clube futebolístico para apoiar.

DEOS, Simone Silva \& MENDONÇA, Ana Rosa Ribeiro. Tendências dos Sistemas Financeiros após a crise e possibilidades de política financeira para a economia brasileira, 2013

WU, Zhongmin. Financial sector reform and the international integration of China, 2008. 